\title{
Peran TV Sekolah sebagai Alternatif Media Pembelajaran Jarak Jauh (PJJ) pada TKIT Al Hikmah
}

\author{
Ifat Latifah ${ }^{1}$, Sri Watini ${ }^{2}$ \\ 1,2Universitas Pancasakti Bekasi, Indonesia \\ E-mail: ifatlatifah72@gmail.com, srie.watini@gmail.com
}

\begin{abstract}
Article Info
Article History

Received: 2021-12-27

Revised: 2022-01-22
\end{abstract}

Published: 2022-02-14

Keywords:

School TV;

Alternative;

Learning Media.

\begin{abstract}
In the current New Normal period, Learning from Home (BDR) and Distance Learning (PJJ) activities have become part of routine activities at school institutions, these activities are carried out by all educational institutions, including early childhood education institutions, it's just that the problems faced is the right learning media for early childhood who have to learn from home (BDR) or distance learning, many learning media currently make early childhood bored with BDR or PJJ. The presence of school TV is an attraction for early childhood education institutions as an alternative learning media in this New Normal era. This research was conducted with a qualitative descriptive research method. Collecting data with interviews, documentation and field notes, the component observed is the role of school TV as an alternative learning media in the period of distance learning (PJJ) and learning from home (BDR). The result of the research is that TKIT Al Hikmah Ciputat has made school TV as an alternative learning media during the PJJ/BDR period.
\end{abstract}

\begin{tabular}{l}
\hline Artikel Info \\
\hline Sejarah Artikel \\
Diterima: $2021-12-27$ \\
Direvisi: 2022-01-22 \\
Dipublikasi: $2022-02-14$
\end{tabular}

Kata kunci:

TV Sekolah;

Media Pembelajaran

JarakJauh;

TKIT.

\begin{abstract}
Abstrak
Di masa New Normal saat ini kegiatan Belajar dari Rumah (BDR) dan Pembelajaran Jarak Jauh (PJJ) sudah menjadi bagian dari kegiatan rutin pada lembaga sekolah, kegiatan ini dilaksanakan semua lembaga pendidikan, tak terkecuali lembaga pendidikan anak usia dini, hanya saja permasalahan yang dihadapi adalah media pembelajaran apayang tepat bagi anak anak usia dini yang harus Belajar dari rumah (BDR) atau Pembelajaran jarak jauh, banyak media pembelajaran yang saat ini membuat anak usia dini jenuh dengan BDR atau PJJ. Kehadiran TV sekolah menjadi daya Tarik bagi lembaga Pendidikan anak usia dini sebagai salah satu alternative media pembelajaran di era New Normal ini. Penelitian ini dilakukan dengan metode penelitian deskriptif kualitatif. Pengumpulan data dengan wawancara, dokumentasi dan catatan lapangan, komponen yang di amati adalah peran TV sekolah sebagai alternative media pembelajaran dimasa Pembelajaran jarak jauh (PJJ) dan belajar dari rumah (BDR). Hasil dari penelitian bahwa TKIT Al Hikmah Ciputat telah menjadikan TV sekolah sebagai alternative media pembelajaran di masa PJJ/ BDR.
\end{abstract}

\section{PENDAHULUAN}

Di masa New Normal yang saat ini masih terus berlangsung hampir semua kegiatan dilakukan secara Work From Home, pembelajaran jarak jauh dan belajar dari rumah, dari jenjang perguruan tinggi sampai jenjang pendidikan anak usia dini. Hal ini menjadi tantangan tersendiri bagi guru guru PAUD yang awalnya tidak memahami kecanggihan tehnologi gadget, kini dipaksa untuk menggunakan media pembelajaran dengan mempergunakan gawai atau laptop. Media pembelajaran yang harus disesuaikan dengan situasi dan kondisi saat ini tentunya membuat pendidik untuk terus mencari alternatif yang sesuai dan tepat dengan perkembangan anak meskipun peserta didik berada di rumah, solusinya pendidik dituntut mendesain media pembelajaran sebagai inovasi dengan memanfaatkan media daring (online), ini sesuai dengan Menteri Pendidikan dan Kebudayaan Republik Indonesia terkait Surat Edaran Nomor 4 Tahun 2020 tentang Pelaksanaan Kebijakan Pendidikan dalam Masa Darurat Penyebaran Corona Virus Disease (Covid-19) (Atsani, 2020).

Media pembelajaran adalah komponen sumber belajar atau wahana fisik yang mengandung materi instruksional di lingkungan siswa yang dapat merangsang siswa untuk belajar, (Arsyad;2016), Sudjana \& Rivai (2015) menyatakan bahwa media pembelajaran merupakan alat bantu mengajar yang ada dalam komponen metodologi, sebagai salah satu lingkungan belajar yang diatur oleh pengajar, sedangkan menurut Sadiman dkk (2014) media pengajaran merupakan segala sesuatu yang digunakan untuk menyalurkan pesan dari pengirim ke penerima sehingga dapat merangsang pikiran, perasaan perhatian dan minat penerima sedemikian rupa 
sehingga proses belajar yang baik dapat terjadi. Ciri-ciri Media Pembelajaran Menurut Arsyad (2016) adalah sebagai berikut:

1. Media pendidikan memiliki pengertian fisik yang dewasa ini dikenal sebagai hardware (perangkat keras), yaitu suatu benda yang dapat dilihat, didengar, atau diraba dengan panca indera.

2. Media pendidikan memiliki pengertian nonfisik yang dikenal sebagai software (perangkat lunak) yaitu kandungan pesan yang terdapat dalam perangkat keras yang merupakan isi yang ingin disampaikan kepada siswa.

3. Penekanan media pendidikan terdapat pada visual dan audio.

4. Media pendidikan memiliki pangertian alat bantu pada proses belajar baik di dalam maupun di luar kelas.

5. Media pendidikan digunakan dalam rangka komunikasi dan interaksi guru dan siswa dalam proses pembelajaran.

6. Media pendidikan dapat digunakan secara masal (misalnya radio, televisi), kelompok besar dan kelompok kecil (misalnya film, slide, video, OHP) atau perorangan (misalnya: modul, komputer, radio tape/kaset, video recorder).

7. Sikap, perbuatan, organisasi, strategi dan manajemen yang berhubungan dengan penerapan suatu ilmu.

Media memiliki peran yang sangat penting dalam pendidikan sebagai suatu sarana atau perangkat yang berfungsi sebagai perantara atau saluran dalam suatu proses komunikasi antara komunikator dan komunikan (Asyar, 2011). Media adalah alat bantu apa saja yang dapat dijadikan sebagai penyalur pesan guna mencapai tujuan pengajaran (Djamarah, 2002), dimana media dapat menampilkan informasi melalui suara, gambar, gerakan dan warna, baik secara alami maupun manipulasi, sehingga membantu guru untuk menciptakan suasana belajar menjadi lebih hidup, tidak monoton dan tidak membosankan. Gagne dan Briggs (1975) dalam Arsyad (2011:4) mengemukakan bahwa media pembelajaran meliputi alat yang secara fisik digunakan untuk menyampaikan isi materi pengajaran, yang terdiri dari antara lain buku, tape recorder, kaset, video camera, video recorder, film, slide (gambar bingkai), foto gambar, grafik, televisi, dan komputer. Secara umum media pembelajaran dapat dikelompokan menjadi empat yaitu:

1. Media Visual yaitu suatu jenis media yang semata-mata hanya memanfaatkan inde- ra penglihatan peserta didik untuk menyampaikan pesan pembelajaran, dengan demikian penggunaan media pembelajaran ini tergantung dari kemampuan penglihatan peserta didik. Sebagai contoh media cetak, seperti buku, modul, jurnal, poster dan peta, model seperti globe bumi dan miniatur dan media realitas alam sekitar.

2. Media Audio yaitu jenis media pembelajaran dengan hanya melibatkan indera pendengaran peserta didik. Pesan dan informasi yang diterimanya adalah berupa pesan verbal seperti bahasa lisan dan pesan nonverbal dalam bentuk bunyi-bunyian, musik dan bunyi tiruan.

3. Media audio-visual adalah jenis media yang digunakan dalam kegiatan pembelajaran dengan melibatkan indera penglihatan dan indera pendengaran dalam suatu proses atau kegiatan. Pesan dan informasi yang dapat disalurkan melalui media ini dapat berupa pesan verbal dan nonverbal yang mengandalkan baik penglihatan maupun pendengaran. Sebagai contoh film, program TV dan video.

Media pembelajaran untuk anak usia dini memiliki beberapa prinsip sesuai kaidah perkembangan dan pertumbuhan anak usia dini. Prinsip Media Pembelajaran untuk Anak Usia Dini Menurut Asnawir, 2002:19-25 antara lain sebagai berikut:

1. Penggunaan media pengajaran hendaknya dipandang sebagai bagian penting yang harus ada dari suatu sistem pengajaran dan bukan hanya sebagai alat bantu yang berfungsi sebagai tambahan yang digunakan bila dianggap perlu dan hanya dimanfaatkan sewaktu-waktu.

2. Media pengajaran harus dipandang sebagai sumber belajar yang digunakan dalam usaha memecahkan masalah- masalah yang dihadapi dalam proses belajar-mengajar karena dalam proses belajar mengajar guru benar-benar menguasai teknik-teknik dari suatu media pengajaran yang digunakan. Namun juga seharus memperhitungkan untung ruginya pemanfaatan suatu media pengajaran.

3. Dalam penggunaan media pengajaran harus diorganisir secara sistematis bukan sembarang mengunakannya, dimana pada saat menggunakan media pembelajaran guru harus benar-benar merancang perencanaan kegiatan dari rumah dan menerapnya pada saat pembelajaran, anak tinggal mengikuti instruktur dari guru. 
4. Guru dapat memanfaatkan multimedia yang menguntungkan dan memperlancar proses belajar- mengajar dan juga dapat merangsang anak aktif dalam belajar jika sekiranya suatu pokok bahasan memerlukan lebih dari satu macam media pembelajaran.

Media pembelajaran untuk anak usia dini itu luas, bukan hanya media yang sengaja dirancang dan di desain oleh guru saja akan tetapi benda apapun bisa dijadikan media pembelajaran selagi benda itu memiliki nilai edukasi, dalam pembuatan media pembelajaran ini menurut Mansur (2008:53) ada beberapa prinsip yang harus diperhatikan dalam pembuatan media yaitu media pembelajaran yang dibuat hendaknya dapat digunakan untuk mengembangkan berbagai aspek perkembangan anak dan dapat dijadikan sebagai media pembelajaran secara berulang. TV sekolah merupakan salah satu alternatif media pembelajaran yang dapat diterapkan pada lembaga Pendidikan anak usia dini, TV sebutan familiar dari Televisi. TV merupakan media sosial sebagai sarana penyiaran dalam bentuk gambargambar yang disertai suara atau bunyi, secara terminologis istilah televisi berasal dari Bahasa Latin "tele" dan "vision" yang artinya melihat sesuatu dari jarak jauh, dalam perkembangannya TV sebagai media informasi yang sangat efektif, karena kapanpun kita dengan mudah untuk mendapatkan informasi-informasi baru sesuai dengan kebutuhan dari berbagai channel, tidak saja informasi yang disajikan akan tetapi juga sebagai sarana hiburan dari berbagai usia mulai dari anak usia dini sampai orang tua, dengan hadirnya TV sekolah ternyata dapat menjadi alternatif media pembelajaran bagi lembaga pendidikan anak usia dini pada saat Pembelajaran Jarak Jauh atau belajar dari rumah seperti saat ini.

Di masa era new Normal keberadaan TV sekolah sebagai Media Pembelajaran di Lembaga PAUD hal ini sangat menarik untuk dijadikan penelitian, bagaimana TV sekolah dapat dijadikan sebagai alternative media pembelajaran yang dapat memudahkan anak anak untuk terus dapat berinteraksi dengan Guru di sekolah seperti yang mereka rasakan di sekolah. TV Sekolah ini berbeda dengan TV yang saat ini ada, TV sekolah dibuat oleh sekolah dengan kegiatan yang sudah di atur oleh sekolah dengan pengisi kegiatan dari Guru guru sekolah yang mengajar dilembaga tersebut. Adapun semua program yang dimasukkan ke dalam TV Sekolah harus melalui verifikator tingkat sekolah yang diketahui oleh kepala sekolah sehingga konten yang dimasukkan ke dalam program TV Sekolah aman, jauh dari kekerasan, buliying, SARA dan konten-konten lainya yang tidak memiliki nilai edukatif bahkan melanggar norma dan etika penyiaran, karena semua agenda kegiatan dan pengisi yang dimasukkan dalam TV sekolah adalah hasil dari kreasi dan inovasi Guru lembaga, dalam TV sekolah itu memiliki fitur utama yang bervariasi,panggung sekolah, perpustakaan digital, kelas virtual dan ekstrakurikuler. TKIT Al Hikmah adalah Taman Kanak-Kanak Terpadu yang menerapkan nilai nilai agama Islam secara berjenjang dan berkelanjutan.

Menurut Sri Watini Dkk 2020, "Kaidah Ilmu Islam dapat pula dilakukan melalui inisiatif pribadi dengan proses pendidikan yang diberikan secara berjenjang dan berkelanjutan, maka perlu ditanamkan jiwa agama yang kuat dalam diri seseorang mulai sejak dini. Setelah itu diajarkan dasar-dasar ilmu agama yang kuat, diajarkan Al-Qur'an baik dari segi membaca maupun memahami isinya, selain itu diajarkan pula hubungan antara satu ilmu dengan ilmu lainnya secara umum, selanjutnya ia mempelajari berbagai bidang ilmu dan keahlian sesuai dengan bidang yang diminatinya", dalam Islam mengajarkan bahwa anak anak pun di perintahkan untuk belajar tehnologi agar anak anak mengenal tehnologi, salah satu contohnya adalah TV sekolah. TKIT Al Hikmah mencoba untuk menjadikan TV sekolah ini sebagai Alternatif media Pembelajaran di masa Pembelajaran jarak jauh /PJJ, dan ternyata menjadi sesuatu yang menarik dan tantangan tersendiri bagi guru untuk berusaha mengisi kegiatan di TV Sekolah dengan mengirimkan video pembelajaran yang menarik untuk dikirimkan ke TV Sekolah.

\section{METODE PENELITIAN}

Metode yang digunakan dalam penelitian ini adalah metode penelitian deskriptif, metode penelitian deskriptif adalah suatu metode riset yang memiliki tujuan untuk menjelaskan secara spesifik peristiwa alam dan sosial yang terjadi di masyarakat (Punaji2021), sedangkan menurut Narbuko dan Ahmadi,2018 Penelitian deskriptif adalah suatu penelitian yang berusaha menjawab permasalahan yang ada berdasarkan data-data. Proses analisis dalam penelitian deskriptif yaitu, menyajikan, menganalisis dan menginterpretasikan. Menurut (Arikunto 2019 Penelitian deskriptif ialah penelitian yang dimaksudkan untuk menyelidiki suatu kondisi, keadaan atau peristiwa lain, kemudian hasilnya akan dipaparkan dalam bentuk laporan penelitian, dalam peneli- 
tian ini peneliti menerapkan deskriptif kwalitatif yang akan memberikan data-data atau dokumen secara lengkap, teratur, bertahap dan berkesinambungan sehingga mampu memberikan informasi yang valid, dapat dipercaya, otentik dan bisa dibuktikan kebenarannya. Teknik pengumpulan data menggunakan interview atau wawancara, observasi dan dokumentasi. Interview atau wawancara yang sering dikenal dengan interview lisan adalah sebuah dialog yang dilakukan oleh pewawancara (interviewer) untuk memperoleh informasi dari terwawancara

\section{HASIL DAN PEMBAHASAN}

Di masa era new Normal saat ini adalah bagaimana guru dapat beradaptasi dengan keadaan dan lingkungan model sekolah dimana guru berada, saat ini guru dituntut untuk dapat menyajaikan model pembelajaran yang kreaatif dan inovatif agar pesaan yang disampaikan dalam kegiatan sekolah tersaampaikan kepada anak-anak. Keberadaan TV sekolah sebagai Media Pembelajaran di Lembaga PAUD hal ini sangat menarik untuk dijadikan penelitian, bagaimana TV sekolah dapat dijadikan sebagai alternatif media pembelajaran yang dapat memudahkan anak anak untuk terus dapat berinteraksi dengan Guru di sekolah seperti yang mereka rasakan di sekolah, TV Sekolah berbeda dengan TV yang saat ini ada, "TV sekolah Memiliki hak Cipta atas nama Sri watini, Dkk, dengan nomor pencatatan 000224874 yang diterbitkan pada tanggal 1 Juli 2020 di Jakarta". TV Sekolah ini dapat dimanfaatkan lembaga Pendidikan anak usia dini sebagai alternatif media pembelajaran dengan kegiatan yang sudah diatur oleh sekolah, dengan pengisi kegiatan dari Guru guru sekolah yang mengajar dilembaga tersebut. Adapun semua program yang dimasukkan ke dalam TV Sekolah harus melalui verifikator tingkat sekolah yang diketahui oleh kepala sekolah sehingga konten yang dimasukkan ke dalam program TV Sekolah aman, jauh dari kekerasan, buliying, SARA dan konten-konten lainya yang tidak memiliki nilai edukatif bahkan melanggar norma dan etika penyiaran, karena semua agenda kegiatan dan pengisi yang dimasukkan dalam TV sekolah adalah hasil dari kreasi dan inovasi Guru lembaga, dalam TV sekolah itu memiliki fitur utama yang bervaria-si, panggung sekolah, perpustakaan digital, kelas virtual dan ekstrakurikuler.

TKIT Al Hikmah mencoba untuk menjadikan TV sekolah ini sebagai Alternatif media Pembelajaran di masa Pembelajaran jarak jauh/PJJ dan ternyata menjadi sesuatu yang menarik dan tantangan tersendiri bagi guru untuk berusaha mengisi kegiatan di TV Sekolah dengan mengirimkan video pembelajaran yang menarik untuk dikirimkan ke TV Sekolah. Proses pemanfaatan TV Sekolah di TKIT Al Hikmah adalah sebagai berikut:

1. Mendaftarkan untuk mendapatkan canel TV Sekolah.

2. Mendaftar dengan akun sekolah dan mengisi biodata sekolah dengan lengkap.

3. Proses verifikator dari TV Sekolah.

4. Proses pembimbingan untuk mengisi kegiatan di TV Sekolah.

5. Mensosialisasikan TV Sekolah kepada Guru.

6. Membuat Video pembelajaran untuk kegiatan yang akan dan sedang berjalan dan siap di masukkan kedalam program TV Sekolah.

7. Mulai membuat kegiatan pembelajaran untuk TV Sekolah dan mempublish.

Selanjutnya sekolah sudah dapat rutin mempublish kegiatan pembelajaran di chanel TV sekolah lebih menarik dan lebih bervariasi, sehingga anak anak tidak merasa jenuh dengan kegiatan Pembelajaran Jarak Jauh atau Belajar dari Rumah. Berikut tabel pelaksanaan pemanfaatan TV sekolah sebagai media pembelajaran yang dilakukan di TKIT Al Hikmah:

Tabel 1. Pemanfaatan TV Sekolah di TKIT Al Hikmah

\begin{tabular}{llcccc} 
& \multirow{2}{*}{ No } & \multirow{2}{*}{ Kelompok } & Jumlah & \multicolumn{3}{c}{ Penilaian } \\
\cline { 3 - 6 } & & $\mathrm{N}$ & $\mathrm{N}$ & $\mathrm{N}$ \\
& & 6 & 7 & 8 \\
\hline 1 & Guru Kel.bermain & 3 & $\sqrt{ }$ & \\
\hline 2 & Guru Kelompok A & 3 & $\sqrt{ }$ & \\
\hline 3 & Guru Kelompok B & 3 & & \\
\hline
\end{tabular}

Keterangan:

N6 Mulai memanfaatkan TV sekolah sebagai media pembelajaran sepekan sekali

N7 Mulai memanfaatkan TV sekolah sebagai media sepekan 2 kali

N8 Mulai memanfaatkan TV sekolah sebagai media setiap hari

\section{SIMPULAN DAN SARAN}

\section{A. Simpulan}

TKIT Al Hikmah sudah mampu menjadikan TV Sekolah sebagai alternatif media pembelajaran yang dilakukan secara PJJ atau BDR, walaupun pemanfaatan TV Sekolah ini masih dilakukan selama sepekan sekali, tetapi hal ini sudah membuat alternative Media Pembelajaran yang lebih kreatif dan bervariasi serta sesuai dengan kondisi saat New Normal 


\section{B. Saran}

Saran untuk penulis selanjutnya adalah mengkaji lebih dalam dan secara komprehensif terkait Peran TV Sekolah sebagai Alternatif Media Pembelajaran Jarak Jauh.

\section{DAFTAR RUJUKAN}

Andi, D., Abid, M., Sunarsi, D., \& Akbar, I. R. (2021). Implementasi Pendidikan Karakter Melalui Nilai-nilai Kearifan Lokal di Mts Darul Huda Kp. Cimuncang Kabupaten Tasikmalaya. JIIP - Jurnal Ilmiah Ilmu Pendidikan, 4(3), 149-153. https://doi.org/10.54371/jiip.v4i3.227

Chairunnisa, C., Hasanah, N., Masyhuri, A. A., Febriansyah, D., \& Sunarsi, D. (2022). Penggunaan Bahasa Indonesia yang Baik dan Benar serta Etika Menghubungi Dosen melalui Aplikasi WhatsApp. JIIP - Jurnal Ilmiah Ilmu Pendidikan, 5(1), 40-44. https://doi.org/10.54371/jiip.v5i1.382

Efektifitas pembelajaran onlinependidik PAUD ditengah Pandemik 19. https://scholar.google.co.id/citations?view_o $p=v i e w_{-}$citation\&hl=id\&user $=D 8 Y X m 0 A A A A J$ \&citation_for_view $=D 8 Y X-$

mOAAAAJ:PkcyUWeTMhOC

Gifari Annisa Rohani, (2020)Pengaruh Televisi (TV) terhadap aspek aspek perkembangan anak usia 3-4 tahun http://dx.doi.org/10.21831/jpa.v4i2.12355

Kurnia dewi; (2020) Pentingnya media pembelajaran bagi anak usia dini; https://core.ac.uk/download/pdf/26794680 8.pdf

media pembeklajaran berbasis tehnologi informasi,https://journal.uny.ac.id/index.ph p/jpakun/article/view/949/0

Sabardila; Menakar nilai pendidikan karakter Acara televisi pada anak usia 6-8 tahun; Jurnal https://doi.org/10.31004/obsesi.v6i1.875
Siti maymunah, sri Watini, (2021) Pemanfaatan media video dalam pembelajaran anak usia dini dimasa pandemic covid-19,Jurnal Pendidikan Tambusai, Vol. 5 No. 2 (2021):2021

Sri watini (2021); Implementasi model pembelajaran,

https://obsesi.or.id/index.php/obsesi/article Lview/190/pdf

Sri watini dkk, HKI Kemenhumham atas nama dengan nomor pencatatan 00224874 tertanggal 1 Juli 2020; Jakarta

Sri Watini, (2021) TV Sekolah; https://tvsekolah.id/tentangkami

Sri watini, Artikel TV Sekolah untuk pembelajaran Asyik di era New Normal, https://www.kompasiana.com/sigitward/5f 48dd2f097f3614fd03e103/tv-sekolah-untukpembelaran-asyik-di-era-new-normal.

Sri watini, Teori kunatum baru yang sesuai Sains dan tehnologi dengan kaida ilmu Islam , https://doi.org/10.34306/abdi.v2i1.450

Suprihatin, L., \& Sunarsi, D. (2021). Pengaruh Kepemimpinan Transaksional dan Lingkungan Kerja Terhadap Kinerja Pegawai di Pusat Pendidikan dan Pelatihan Pegawai Kementerian Pendidikan dan Kebudayaan. JIIP - Jurnal Ilmiah Ilmu Pendidikan, 4(1), $\quad$ 78-86. https://doi.org/10.54371/jiip.v4i1.207

Syarif Hidayatullah Syihabudin, Vismaia Damayant (2020); Analisis kebutuhan Media Literasi berbasis digital pada anak usia dini Jurnal https://doi.org/10.31004/obsesi.v6i3. $\underline{1183}$

Zaman, B.PD.M \& Eliyawati.C.H.(2010), Media Pembelajaran anak usia dini,In media Pembelajaran anak usia dinirwokerto 